\title{
CHEMICAL COMPOSITION OF THE ESSENTIAL OIL OF MILIUSA BAILLONII PIERRE (ANNONACEAE) FROM VIETNAM
}

\author{
TRAN MINH HOI \\ Institute of Ecology and Biological Resources \\ DO NGOC DAI, TRAN DINH THANG \\ Vinh University \\ NGUYEN XUAN DUNG \\ Hanoi National University
}

\begin{abstract}
The leaf oil of Miliusa baillonii Pierre (Annonaceae) collected of Phong Nha - Ke Bang national park, Vietnam, in March 2007 was isolated by steam distillation to give oil yield $0.15 \%$ and analyzed by Capillary GC and GC/MS. Forty six components have been identified accounting more than $92.8 \%$ of the oil. The major constituents of this oil appeared to be z-citral $(41.2 \%), \beta$-caryophyllene $(10.6 \%)$ and $\alpha$-humulene (6.2\%).
\end{abstract}

The genus Miliusa Lechen ex A. DC. comprises about 50 species that are widely distributed through the Indian subcontinent, Burma, Indo-China, Malaysia and Australia [1, 2]. The different species of Miliusa are invariably small to large trees and are found in a wide range of rainforest communities. Whilst the phylogeny of the Annonaceae remains to be satisfactorily resolved, Miliusa is thought to be allied to the genera Orophea Blume, Mezzettiopsis Ridley, Plioenicanthus Alston, Alphonsae Hook. f. \& Thorns., Platymitra Boerl. and Mezzettia Becc. [2, 3]. Only three species of Miliusa occur in Australia, with two essential oil these being endemic [4]. Some extra species of Miliusa have been reported to contain alkaloids.

Two new isoquinoline alkaloids, 2,10dimethoxy-3,11-dihydroxy-5,6-dihydroprotober -berine and 1,9-dihydroxy-2,11 -dimethoxy-4,5dihydro-7-oxoaporphine, together with thirteen known alkaloids, were isolated from the ethanolic extracts of the stem and leaves of $M$. cuneata (Graib) [4]. Selective toxicity was also observed for 10-methoxyliriodenine (lauterine) and 10-hydroxyliriodenine, two oxoaporphine alkaloids isolated from $M$. banacea [5]. Until now only 6 Miliusa, M. baillonii, M. balanse,
M. banpoientes, $M$. campanulata, $M$. sinensis and $M$. velutima were found in Vietnam [7].

The leaf oil obtained from $M$. traceyi contained a mixture of mono- and sesquiterpenes. The principal monoterpenes were the hydrocarbons $\alpha$-pinene (10-19\%) and $\beta$-pinene (13-19\%). The only other monoterpene present at $>1 \%$ was limonene $(2-4 \%)$. While the usually encountered monoterpene hydrocarbons were present, they did not account individually for more than $0.3 \%$. A large number of sesquiterpenes were present in the oil, but only a few accounted for more than $5 \%$. The main members were $\beta$-caryophyllene (9$14 \%), \quad$ germacrene D (4-6\%), bicyclogermacrene (3-10\%) [6].

Miliusa horsfield presented leaf oil which was essentially sesquiterpenic. The full suite of monoterpene hydrocarbons were present, but in total accounted for less than $2 \%$. The major sesquiterpenes encountered in the leaf oil were $\alpha$-copaene $(5-8 \%), \beta$-caryophyllene $(12-21 \%)$, $\alpha$-liuinulciie (3-4\%), $\alpha$-and $\beta$-selincne (each t$3 \%)$, bicyclogerniacrene $(2-4 \%), \delta$-cadinene $(3-$ $5 \%$ and caryophyllene oxide (12-15\%). Unidentified oxygenated sesquiterpenes accounted for up to $10 \%$ of the oil. The oil yield, based on fresh leaves, was $0.1 \%$ [6]. 
Miliusa braliei gave oil in which sesquiterpenes predominated to a very large extent. The major sesquiterpenes encountered were $\beta$-caryophyllene (10-25\%), $\alpha$-humulene (10$13 \%)$, germacrene $\mathrm{D}(1-6 \%), \alpha$ - and $\beta$-selinene (both 1-3\%), bicyclogermacrene (0.7-13\%), globulol (3-7\%), viridiflorene (1-3\%), spathulenol (3-5\%) and caryophyllene oxide (1-5\%). The major monoterpenes detected were (Z)- $\beta$-ocimene (0.4-3\%), linalool (0.6-8\%, the majority being > $5 \%), \alpha$-terpineol (3-7\%), geraniol (1-3\%) and geranyl acetate $(0.1-0.3 \%)$. It is, presumably, these latter oxygenated monoterpenes which are responsible for the 'raspberry jelly tree' name given to the species that pertains to the smell of the crushed foliage [6].

M. baillonii Pierre $15-30 \mathrm{~m}$ tall, is found in Dak Lak, Dong Nai, An Giang, Quang Binh (Phong Nha - Ke Bang) and Cambodia [6].

To the best of our knowledge, nothing is known about the chemical composition of essential oil of $M$. baillonii. For this reason, the objective of this study is to identify the volatile constituents (of the leaf oil) of Miliusa baillonii from Phong Nha - Ke Bang national park, Vietnam.

\section{EXPERIMENTAL}

1. Source - The leaves of Miliusa baillonii were collected in April 2007, in Phong Nha - Ke Bang national park, Quang Binh province and identified by Assoc. Prof. Dr. Vu Xuan Phuong of Institute of Ecology and Biological Resources. A voucher specimen (DD110) was deposited at the Herbarium of the Institute of Ecology and Biological Resources, Vietnamese
Academy of Science and Technology.

Fresh leaves were shredded and their oil was obtained by steam distillation for $3 \mathrm{~h}$ at normal pressure, according to the Vietnamese Pharmacopoeia [8]. The yield of the fresh leaf oil was $0.15 \%$.

2. $\boldsymbol{G C}$ - About $15 \mathrm{mg}$ of oil, which was dried with anhydrous sodium sulfate, was dissolved in $1 \mathrm{ml}$ of $\mathrm{n}$-hexane (for spectroscopy or chromatography).

GC analysis was performed on an Agilent Technologies HP 6890 Plus Gas chromatograph equipped with a FID and fitted with HP-5MS column $(\mathrm{L}=30 \mathrm{~m}$, ID $=0.25 \mathrm{~mm}$, film thickness $=0.25 \mu \mathrm{m})$. The analytical conditions were: carrier gas $\mathrm{H}_{2}$, injector temperature (PTV) $250^{\circ} \mathrm{C}$, detector temperature $260^{\circ} \mathrm{C}$, temperature programmed $60^{\circ}(2 \mathrm{~min}$ hold $)$ to $220^{\circ}(10 \mathrm{~min}$ hold) at $4^{\circ} \mathrm{C} / \mathrm{min}$.

3. $\boldsymbol{G C} / \boldsymbol{M S}$ - An Agilent Tech HP $6890 \mathrm{~N}$ Plus Chromatograph was fitted with a fused silica capillary col. HP-5MS column $(\mathrm{L}=30 \mathrm{~m}$, ID $=0.25 \mathrm{~mm}$, film thickness $=0.25 \mu \mathrm{m})$. The condition of use were the same as described above with $\mathrm{He}$ as carrier gas, and interface with a mass spectrometer HP $5973 \mathrm{MSD}(70 \mathrm{eV})$. The temperature was programmed as reported above. Component identification was carried out by comparing MS data with those reported in Library Willey on Chemstation HP, and in some cases substances identified from oils known composition and also with standard substances [9-12].

\section{RESULTS AND DISCUSSION}

Table 1

\section{Chemical constituent of essential oil of Miliusa baillonii Pierre from Phong Nha - Ke Bang national park, Vietnam}

\begin{tabular}{|c|l|c|c|}
\hline $\mathbf{N}^{\mathbf{0}}$ & \multicolumn{1}{|c|}{ Compounds } & KI & \%FID \\
\hline 1 & 6-methyl-5-hepten-2-one & 978 & 0.7 \\
\hline 2 & myrcene & 990 & 0.2 \\
\hline 3 & limonene & 1032 & 0.4 \\
\hline 4 & furan (perillene) & 1037 & 0.3 \\
\hline 5 & (E)- $\beta$-ocimene & 1052 & 0.7 \\
\hline 6 & $\alpha$-terpinolene & 1090 & 1.5 \\
\hline 7 & linalool & 1100 & 2.7 \\
\hline 8 & alloocimene & 1128 & 0.1 \\
\hline
\end{tabular}




\begin{tabular}{|c|c|c|c|}
\hline 9 & cis verbenol & 1141 & 0.2 \\
\hline 10 & cis-carveol & 1229 & 0.2 \\
\hline 11 & geraniol & 1253 & 0.5 \\
\hline 12 & z-citral & 1318 & 41.2 \\
\hline 13 & bicycloelemene & 1327 & 1.1 \\
\hline 14 & $\alpha$-cubebene & 1351 & 0.3 \\
\hline 15 & $\alpha$-longipinene & 1353 & 0.1 \\
\hline 16 & $\alpha$-ylangene & 1375 & 0.1 \\
\hline 17 & $\alpha$-copaene & 1377 & 0.3 \\
\hline 18 & $\alpha$-copaene & 1377 & 0.3 \\
\hline 19 & $\beta$-cubebene & 1388 & 0.3 \\
\hline 20 & isolongifolene & 1390 & 1.2 \\
\hline 21 & $\beta$-elemene & 1391 & 3.5 \\
\hline 22 & $\beta$-elemene & 1391 & 0.7 \\
\hline 23 & isocaryophyllene (bicyclo[7.2.0]undec-4-ene) & 1409 & 2.6 \\
\hline 24 & $\beta$-caryophyllene & 1419 & 10.6 \\
\hline 25 & calarene & 1434 & 0.2 \\
\hline 26 & $\gamma$-elemene & 1437 & 1.0 \\
\hline 27 & aromadendrene & 1441 & 1.0 \\
\hline 28 & $\alpha$-humulene & 1455 & 6.2 \\
\hline 29 & dehydroaromadendrene & 1463 & 0.2 \\
\hline 30 & naphthalene & 1464 & 1.0 \\
\hline 31 & germacrene D & 1485 & 1.2 \\
\hline 32 & cadina-1,4-diene & 1496 & 0.2 \\
\hline 33 & $(\mathrm{E}, \mathrm{E})-\alpha$-farnesen & 1508 & 0.4 \\
\hline 34 & $\delta$-cadinene & 1525 & 1.4 \\
\hline 35 & (Z)-nerolidol & 1533 & 0.2 \\
\hline 36 & $\alpha$-cadinene & 1539 & 0.1 \\
\hline 37 & elemol & 1550 & 1.7 \\
\hline 38 & germacrene B & 1561 & 1.2 \\
\hline 39 & Ledol & 1569 & 0.3 \\
\hline 40 & spathoulenol & 1578 & 1.4 \\
\hline 41 & viridiflorol & 1593 & 0.6 \\
\hline 42 & Guaiol & 1601 & 0.2 \\
\hline 43 & allo aromadendrene & 1641 & 0.3 \\
\hline 44 & $\tau$-muurolol & 1646 & 3.8 \\
\hline 45 & calamenene & 1702 & 0.3 \\
\hline 46 & Lanceol & 1761 & 0.1 \\
\hline
\end{tabular}

Note: trace $<0.1 \%$; KI: Kovas Index.

The leaf oil of Miliusa baillonii Pierre was isolated by steam distillation to give oil yield $0.15 \%$ and analyzed by Capillary GC and GC/MS. Forty six components have been identified accounting more than $92.8 \%$ of the oil. The major constituents of this oil appeared to be z-citral (41.2\%), $\beta$-caryophyllene (10.6\%), $\alpha$-humulene $(6.2 \%)$.
Less predominant constituents included $\tau$ muurolol $(3.8 \%), \beta$-elemene $(3.5 \%)$, linalool $(2.7 \%)$, isocaryophyllene $(2.6 \%)$, elemol $(1.7 \%), \quad \alpha$-terpinolene $(1.5 \%), \quad$ spathoulenol $(1.4 \%), \quad \delta$-cadinene $1.4 \%), \quad$ isolongifolene $(1.2 \%)$, germacrene B $(1.2 \%)$, germacrene D $(1.2 \%)$ and bicycloelemene $(1.1 \%)$. All the other components were in concentration of less 
than $0.1-1.0 \%$.

\section{CONCLUSIONS}

The leaf oil of Miliusa baillonii Pierre collected from Phong Nha - Ke Bang national park, Quang Binh province in April 2007 was isolated by steam distillation to give oil yield $0.15 \%$ and analyzed by Capillary GC and GC/MS. Forty six components have been identified accounting more than $92.8 \%$ of the oil. The major constituents of this oil appeared to be z-citral (41.2\%), $\beta$-caryophyllene (10.6\%), $\alpha$-humulene $(6.2 \%)$.

\section{REFERENCES}

1. Sinclair J., 1955: A revision of the Malayan Annonaceae, Gardens Bulletin Singapore, 14: 149-516.

2. Kessler P. J. A., 1993: Annonaceae. In: The Families and Genera of Vascular Plants. Edits., K.Kubitzki, J. G. Rohwer and V. Bittrich, 2, 93-129, Springer-Verlag, Berlin/Heidelberg.

3. Kessler P. J. A., 1995: Rheedea, 5: 97-102.

4. Jessup L. W., 1988: The genus Miliusa Leschen, ex A. DC. (Annonaceae) in Australia, Austrobaileya, 2: 517-523.
5. Harrigan G. A., Gunatilake A. A. L. and Kingston D. G. I., 1994: J. Nat, Prod., 57: 68-73.

6. Brophy J. J., Goldsack R. J., Forster P. I., 2004: J. Essent. Oil Res., 16(3): 253-255.

7. Nguyen Tien Ban, 2000: Flora of Viet Nam, Vol. 1., Annonaceae. Science and Technics Publishing House, Hanoi, Vietnam. Pp. 305-315.

8. Vietnamese Pharmacopoeia, 1997: Medical Publishing House, Hanoi, Vietnam. 664 pp.

9. Adams R. P., 2001: Identification of Essential Oil Components by Gas Chromatography/Quadrupole Mass Spectrometry, Allured Publishing Corp. Carol Stream, IL., 456pp.

10. Stenhagen E., Abrahamsson S. and McLafferty F. W., 1974: Registry of Mass Spectral Data, Wiley, New York, 3358 pp.

11. Joulain D. and Koenig W. A., 1998: The Atlas of Spectral Data of Sesquiterpene Hydrocarbons, E. B. Verlag, Hamburg, 658 pp.

12. Swigar A. A. and Siverstein R. M., 1981: Monoterpenens, Aldrich, Milwaukee, $130 \mathrm{pp}$.

\title{
THÀNH PHẦN HÓA HOC TINH DẦU LÁ LOÀI MAAI LIỄU BAILONI (MILIUSA BAILONIII PIERRE) Ở VIẸT NAM
}

\author{
TRẦN MINH HỢI, ĐỖ NGOC ĐÀI, \\ TRẦN ĐİNH THẤNG, NGUYỄN XUÂN DŨNG
}

\section{TÓM TÁT}

Nghiên cứu thành phần hoá học tinh dầu lá loài mại liễu bailloni (Miliusa bailonii Pierre). Thu tại Vườn quốc gia Phong Nha - Kẻ Bàng vào tháng 3 năm 2007. Hàm lượng tinh dâuu theo nguyên liệu tươi là $0,15 \%$. Bằng phương pháp sắc ký khí (GC) và sắc ký khí khối phổ liên hợp (GC/MS) hơn 50 hợp chất đã được tách ra, trong đó đã xác định được 46 hợp chất (chiếm $92,8 \%$ tổng hàm lượng tinh dầu). Thành phần chính tinh dầu của lá là z-citral $(41,2 \%), \beta$-caryophyllen $(10,6 \%), \alpha$-humulen $(6,2 \%)$. 